\title{
A Descoberta do Novo Mundo e a Crise da Ideia de Natureza Humana Universal
}

The New World Discovery and the Crisis of Human Nature View Universal

\section{Danilo Marcondes"}

Resumo: Proponho aqui uma discussão sobre os questionamentos à universalidade da natureza humana levantados pelo contato entre os europeus e o Novo Mundo, desde o final do século XV e início do XVI, ou seja, no contexto histórico do Renascimento. Esse questionamento se dá também no momento de discussão sobre os direitos dos povos conquistados. A crise no pensamento suscitada por essa discussão contribuiu decisivamente para o desenvolvimento do ceticismo moderno.

Palavras-chave: Novo Mundo, Renascimento, Natureza Humana, Ceticismo

Abstract: I propose to discuss the questioning of traditional theories on the universality of human nature in consequence of the discovery of the New World in the context of the Renaissance and in the beginning of modern thought. This had important consequences for the rights of the people of New World and contributed directly to the development of modern scepticism.

Keywords: New World, Renaissance, Human Nature, Scepticism

...quaecumque est hominis definitio, una in omnes valet.

Cícero, De legibus, I.

"Professor do Departamento de Filosofia, PUC-Rio/UFF. 


\section{O contexto dos descobrimentos}

Toda discussão sobre Direitos Humanos pressupõe uma concepção de natureza humana; concepções de pretensão universalista supõem uma natureza humana universal. Os primeiros a formularem teorias sobre a natureza humana em nossa tradição foram os filósofos gregos, notadamente Platão e Aristóteles, e sua teorias, principalmente a aristotélica (por exemplo, na Política), influenciaram muito fortemente o desenvolvimento desta discussão na escolástica medieval, quando reinterpretadas à luz da doutrina cristã, principalmente por São Tomás de Aquino (AQUINAS, 2007).

Contudo, o Renascimento foi um dos momentos mais privilegiados dessa discussão por seu questionamento, em diferentes direções, da tradição aristotélico-tomista e pela retomada de sua corrente rival agostiniano-platônica, ou mesmo de uma nova forma de platonismo, de inspiração bizantina, independente, embora em larga escala compatível com o agostianismo. O Humanismo renascentista, já com Francesco Petrarca no século XIV, teve uma inspiração platônico-agostiniana, procurando fazer com que o homem se voltasse para si mesmo, desviando seu olhar do mundo natural. A retomada dos clássicos no Renascimento trouxe também para o centro da discussão autores esquecidos no período medieval como Protágoras cuja fórmula "o homem é a medida de todas as coisas", que nos chegou através de Platão (no diálogo Teeteto) foi um dos lemas do Humanismo.

O descobrimento do Novo Mundo recoloca em questão as visões da época sobre a natureza humana, sobretudo a aristotélica e pode ser considerado de um ponto de vista histórico uma das origens, se não $a$ origem, da discussão moderna sobre direitos humanos em nossa tradição (DUMONT, 1995). Sobretudo a concepção de uma natureza humana universal e, em consequência, de direitos humanos universais, terá nesse contexto um momento privilegiado de discussão ${ }^{\mathrm{I}}$. Podemos lançar a hipótese de que é nesse momento, antes mesmo do que no Iluminismo e em seus desdobramentos como as declarações de direitos nas revoluções americana e francesa, que essa questão se formula.

Para entendermos o significado e o impacto do descobrimento do Novo Mundo sobre o pensamento europeu dos séculos XVI e XVII devemos levar em conta sobretudo a assim chamada "literatura das navegações", os textos produzidos por navegadores, cronistas, historiadores e cientistas naturais que tendo ou não viajado ao Novo Mundo escreveram sobre as descobertas, procurando entender e avaliar seu impacto e suas

\footnotetext{
${ }^{\text {I }}$ Ver Jullien, 2008. Ver também especificamente a propósito da universalidade dos direitos humanos, "Ce qui n'est pas dit dans la Déclaration de I948, c'est ce qu'il faut entendre par universalité" (Fauré, I988)
} 
consequências. Nosso foco será principalmente sobre o que podemos chamar de primeiras imagens das Américas formadas por essa literatura, concentrando-nos assim no século XVI.

Podemos distinguir inicialmente, em linhas gerais, quatro grandes conjuntos de textos, sobretudo tendo em vista a origem dos autores, mas também a serviço de quem navegavam e a que tipo de "leitor" se dirigiram. Se considerarmos o século XVI há basicamente quatro tipos de literatura: (I) a italiana; (2) a espanhola; (3) a portuguesa; e (4) a francesa.

Em um sentido cronológico os primeiros textos foram escritos por navegadores italianos, os primeiros descobridores do Novo Mundo. Destacam-se Cristóvão Colombo e Américo Vespúcio, mas há também relatos importantes de viagens por Giovanni da Verrazzano e Giovanni da Empoli (Le Nouveau Monde, 2004).

Por outro lado, Pedro Mártir d'Anghiera, um clérigo de origem italiana, conselheiro dos reis de Espanha, embora jamais tenha estado nas Américas, escreveu uma série de textos de grande repercussão e muito difundidos na época, baseados nos relatos dos viajantes (D'ANGHIERA, 2003). Esses autores tinham em sua maioria uma formação humanística e foram influenciados pelo contexto do início do Renascimento na Itália. O mais importante e influente deles foi certamente a carta Novus Mundus de Américo Vespucci, que contribuiu inclusive, dada sua ampla circulação e mesmo popularidade, para que o nome "América" (inicialmente apenas no singular) fosse dado às terras recém descobertas (Le Nouveau Monde, 2005). Esses textos, principalmente os de Colombo, Vespucci e Pedro Mártir, por terem sido os primeiros e devido à autoridade de seus autores, tiveram uma grande influência sobre os que foram produzidos depois, encontrando-se imagens, conceitos, metáforas e até passagens inteiras deles reproduzidos e reiterados em relatos posteriores.

É como se os autores que os sucederam quisessem confirmar o que haviam lido nesses primeiros textos, buscando encontrar nas Américas precisamente aquilo sobre o que haviam lido, aquilo que se esperava que encontrassem, o que lhes parecia reforçar sua autoridade e credibilidade, ao reafirmar essas primeiras imagens.

A literatura de origem portuguesa é menos extensa e foi de menor repercussão, consistindo de épicos de inspiração clássica como os Lusíadas de Camões (I572), de textos que combinam elementos históricos e relatos de viagem desde o Esmeraldo de situ orbis ${ }^{2}$ de Duarte Pacheco Pereira, até o Tratado Descritivo do Brasil (I587) de Gabriel Soares de Souza. Inclui também documentos, em geral relatórios, dirigidos à Coroa como a famosa carta de

\footnotetext{
${ }^{2}$ Redigido entre I503-1506, permaneceu incompleto, publicado só no século XVIII, embora cópias manuscritas circulassem desde o século XVI.
} 
Pero Vaz de Caminha. Os portugueses, que foram pioneiros, possuíam em geral uma visão mais pragmática e preocupavam-se concretamente com questões de cartografia, de técnica das navegações e de comércio com os diferentes povos, produzindo assim uma "ciência" ou ao menos uma "técnica das navegações" desde meados do século XV. As colônias portuguesas na África e na Ásia não foram de início mais do que feitorias e entrepostos comerciais.

A preocupação dos autores franceses deve ser entendida sobre o pano de fundo das guerras religiosas na França, principalmente os textos produzidos após o projeto malogrado da França Antártica no Brasil, a expedição de Villegaignon à baia de Guanabara em I555.

Mas, os textos que nos interessam mais diretamente a propósito da questão dos direitos humanos da discussão sobre a universalidade da natureza humana são os produzidos pelos conquistadores, colonizadores e cronistas espanhóis. Dentre esses há toda uma literatura, de caráter inédito em relação aos dos autores de outras nacionalidades, que revela uma preocupação com a legitimação política, jurídica e religiosa da ocupação pela Coroa da Espanha dos territórios das Américas. Trata-se da questão do "direito de conquista" no contexto da qual emerge, por sua vez, a questão dos direitos humanos, especificamente dos direitos dos nativos, dos povos conquistados. A própria noção de "direito de conquista" é de certa forma paradoxal, uma vez que concretamente a conquista não se "legitima" por um direito, mas resulta sobretudo da vitória do conquistador sobre o conquistado, este o sentido mesmo de "conquista". E foi isso que de fato ocorreu. A preocupação com a legitimação dá-se posteriormente, em sucessivas etapas, como tentativa de justificar a conquista perante outros países europeus e de resolver a controvérsia entre a coroa, os conquistadores e os missionários no processo de ocupação. Embora desde o primeiro momento isso apareça já como uma questão sobre a expansão ou não da conquista e sobre em que condições os novos territórios poderiam ser anexados à Coroa espanhola. Trata-se na verdade de um processo que deve ser visto como parte da expansão dos territórios da Espanha desde a "reconquista" da região de Granada aos mouros cuja data, I492, coincide precisamente com a chegada de Colombo ao Caribe, precedendo-a por alguns meses apenas.

Há muitas hipóteses acerca da preocupação da Coroa de Espanha quanto à discussão sobre seu novo império colonial e este talvez seja efetivamente o primeiro momento em que esta questão é tematizada na tradição ocidental, abrindo um novo caminho de debate sobre o estatuto político dos novos estados que começam então a se configurar. 
Em primeiro lugar, deve-se levar em conta que a Espanha era ainda ao final do século XV um reino recém constituído e mesmo assim precariamente. Isabel de Castela e Fernão de Aragão embora tenham efetivado a integração de seus reinos pelo casamento, reinavam separadamente e Isabel após a sua morte foi sucedida em Castela por sua filha Joana, a Louca e não por Fernão ${ }^{3}$. O primeiro território a pertencer efetivamente ao novo estado foi o reino de Granada após a expulsão definitiva dos mouros, recebendo assim um novo estatuto jurídico, por não pertencer às heranças nem de Isabel, nem de Fernão, incorporando-se à Coroa espanhola por "direito de conquista", já que os reis católicos haviam conseguido expulsar os últimos governantes islâmicos, os infiéis, desse território. Essa expansão territorial servirá em parte de modelo para a discussão sobre a ocupação das Américas, que deve ser entendida nesse contexto, recorrendo igualmente às noções de "direito de conquista" e de "infiéis" ou "pagãos" - nesse caso os habitantes do Novo Mundo (THOMAS, 2003).

Portanto, a unidade territorial da Espanha ainda era naquele momento bastante precária tanto de um ponto de vista político, quanto jurídico. Esse processo se agravou quando o sucessor de Fernão e Isabela, Carlos V (V de Alemanha e I de Espanha, da qual se tornou rei em 1517 após a morte de Fernão) herdou igualmente um vasto número de territórios europeus (Borgonha, Áustria, Boemia, etc.) sendo eleito Imperador da Alemanha (em I520, numa eleição particularmente conturbada). A instabilidade política e a luta jurídica para superá-la são fatores essenciais para entendermos a preocupação da Coroa espanhola com a incorporação ao império de mais um vasto território naquele momento ainda inadequadamente conhecido.

A ideia de uma monarquia universal se encontra já no testamento de Fernão de Aragão a seu neto Carlos e no texto Relación del ideário político de Fernando de autoria de Pedro de Quintana elaborado por encomenda de Fernão (HEER, 1995, p. I60). Há dois pressupostos importantes contidos nessa ideia: (I) o de que os reis de Espanha enquanto reis católicos têm por missão a expansão da Cristandade e a conversão dos infiéis (inicialmente os mouros e os muçulmanos em geral, posteriormente os nativos do Novo Mundo); (2) o de que os reis europeus, e isso se aplicará particularmente a Carlos V, enquanto imperador do Santo Império Romano Germânico, são herdeiros e sucessores do Império Romano com sua pretensão a universalidade.

Essa pretensão universalista da coroa espanhola diz respeito à missão de expansão do Cristianismo e de conversão dos povos infiéis como legitimação da conquista do Novo

\footnotetext{
${ }^{3}$ Em I479 a "Paz de Alcaçovas" sela a união de Castela e Aragão e a paz com Portugal, porém Joana reinou nominalmente em Castela até a sua morte em I555.
} 
Mundo. Para isso Carlos V e os colonizadores das Américas receberam a aprovação da Igreja com base num suposto domínio que esta teria sobre toda a Criação, o que será objeto de grande controvérsia. Já anteriormente, os papas Alexandre VI (bulas Inter caetera, I493 e Dudum siquidem, I493) e Júlio II (bulas Universalis Ecclesiae, 1508 e Eximia Devotionis, I510) dão aos reis de Espanha poder para coletar dízimos e dirigir a Igreja no Novo Mundo, sendo a contrapartida da concessão e do reconhecimento do poder (dominium) dos reis sobre essas novas terras, a ampliação da cristandade.

Ao mesmo tempo, devido à expansão marítima de Portugal e suas pretensões ao trono de Castela por questões de sucessão dinástica, a Espanha possuía uma disputa tradicional do ponto de vista político e territorial com Portugal. Já na conquista pelos espanhóis das ilhas Canárias, o bispo de Sevilha, em nome do Papa, confirmara o direito dos espanhóis como supostos sucessores do reino visigótico que antes da invasão árabe no século VIII, teria incluído parte do norte da África e essas ilhas, o que era no mínimo discutível. Mas é o mesmo tratado de Alcaçovas, a que nos referimos acima (nota 3), que regulamenta essas disputas e estabelece as primeiras regras sobre os territórios ainda a conquistar, no caso na costa africana, precedendo assim em mais de uma década o tratado de Tordesilhas (I494) e a discussão sobre a expansão nos territórios a serem conquistados no Novo Mundo.

\section{A natureza humana no Novo Mundo}

A descoberta do Novo Mundo e a conquista dos novos territórios se dá em três etapas distintas. (I) A primeira é a da perplexidade gerada pelo impacto da descoberta na medida em que não se sabia exatamente onde se havia chegado, mas que resulta sobretudo do primeiro contato com as ilhas do Caribe e não ainda com o continente. Colombo continuou acreditando até o fim de sua vida (1506) e após quatro viagens ao Novo Mundo que havia chegado a algum ponto da Ásia ${ }^{4}$. Além disso, grande parte das espécies da flora e da fauna das terras recém descobertas era desconhecida e não se encontrava nenhuma referência a elas nas obras clássicas da Antiguidade como a Historia Naturalis (c. 77 A.D.) de Plínio, o Velho, naquele momento ainda a principal obra de ciência natural. Mas, é sobretudo a visão dos habitantes do Novo Mundo que causa especial perplexidade, sendo particularmente relevante para nossa análise. O primeiro contato de Colombo com os

\footnotetext{
${ }^{4}$ Até hoje se discute o lugar exato da chegada de Colombo às Américas. Os dois candidatos mais fortes são a ilha de Watling nas Bahamas e mais recentemente a ilha de Samana Cay, também nas Bahamas. Ver GARRRET, National Geographic, 1986.
} 
povos tainos habitantes das Antilhas revela já a dificuldade de entendê-los desde o ponto de vista linguístico, até seus hábitos e costumes. Essa perplexidade resulta principalmente do desconhecimento da existência desses habitantes do Novo Mundo e da diferença radical entre eles, os europeus e os outros povos da África e da Ásia, conhecidos do mundo ocidental em sua grande maioria já desde a Antiguidade (por exemplo, através dos relatos de Herótodo); ou no caso da África Equatorial, pelo menos desde o início das navegações portuguesas no século XV, há algumas décadas, portanto. Colombo enfatiza em seu Diário a acolhida pacífica e mesmo generosa que teve nesse seu primeiro contato (Le Nouveau Monde, op.cit., 2004)

Encontramos, por exemplo, em Américo Vespucci a seguinte descrição:

Esta figura mostra-nos a gente e a ilha descoberta pelo Cristianíssimo rei de Portugal ou por seus súditos. Estas pessoas são nuas, belas e de cor parda, bem feitas de corpo. Sua cabeça, pescoço, braços, partes íntimas e os pés dos homens e mulheres, são ligeiramente cobertos de penas. Os homens também usam na face e no peito muitas pedras preciosas. Ninguém possui nada, mas todas as coisas são comuns. E os homens tomam por esposa as que mais lhe agradam, sejam elas suas mães, irmãs ou amigas, pois não fazem nenhuma distinção. Lutam mutuamente, comem-se uns aos outros, mesmo aqueles que massacram, e penduram a carne sob o fumo. Vivem cento e cinquenta anos. E não possuem governo. ${ }^{5}$

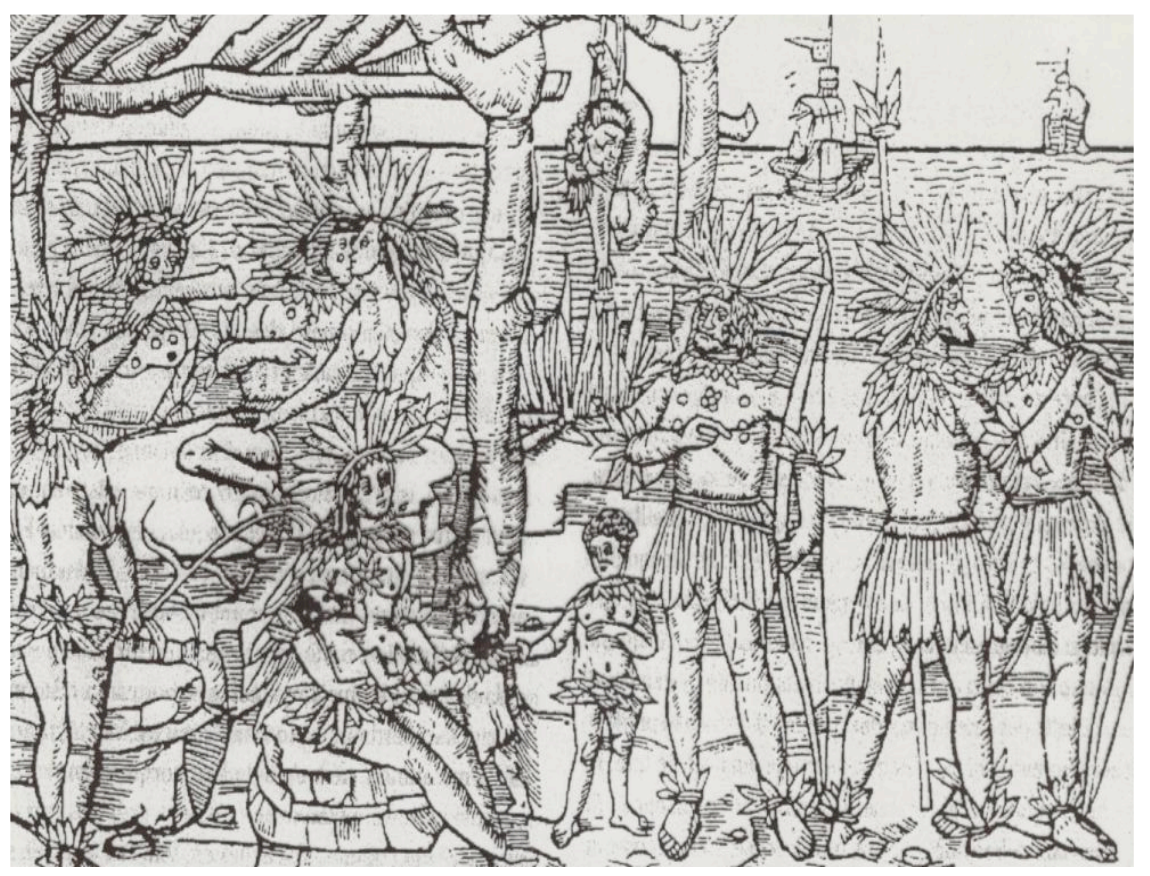

\footnotetext{
${ }^{5}$ Trata-se de legenda a ilustração de texto atribuído a Américo Vespucci em: (TEIXEIRA; PAPAVERO, 2002, p.I25)
} 
Pode-se observar nesse texto o contraponto entre o "indígena" e o homem europeu, desde as características físicas, como a nudez e as penas no corpo, uma óbvia confusão com adereços de penas, até hábitos e práticas como a promiscuidade sexual, já que não possuem noção de pecado. A abundância de pedras preciosas e a ausência de propriedade privada são também aspectos importantes no contraste com a vida na Europa. O canibalismo e a longevidade enfatizam o estilo de vida radicalmente distinto e a inexistência de governo é destacada no texto. Não importa que essa descrição seja pouca precisa e não corresponda aos hábitos e características desses povos, apenas muito posteriormente melhor conhecidos. As pedras preciosas, por exemplo, não eram utilizadas por índios da costa do Brasil; a suposta promiscuidade sexual baseada numa concepção europeia de moralidade, nem sempre ocorria, ao contrário havia tabus sexuais bastante rigorosos, embora a poligamia fosse frequente; a suposta longevidade era ilusória e a ausência de governo simplesmente mostra a dificuldade dos europeus de reconhecer como governo qualquer outra forma que fosse radicalmente diferente dos sistemas por eles conhecidos. Certamente havia formas de gestão e estruturas de poder dentre os indígenas, bastante estudadas pela antropologia mais recentemente. $\mathrm{Na}$ verdade a visão do indígena pelo europeu resulta na fabricação de um ser fantástico, seu oposto, mas também seu espelho. Descrevê-los, procurar compreendê-los, afinal das contas só é possível recorrendo-se à analogia com as categorias tradicionais que, por definição, são inadequadas para isso. A tentativa de conhecimento do novo por analogia com o antigo, segundo o preceito aristotélico, frequentemente fracassa nesses casos. As imagens tradicionais que os europeus trazem baseadas em mitos da Antiguidade Clássica e da literatura medieval de viagens entram em confronto diretamente com essa nova realidade e se revelam muito pouco esclarecedoras.

A segunda etapa (2) consiste na necessidade de uma tomada de posição frente ao mundo recém descoberto, o que será feito recorrendo-se basicamente a duas autoridades: (I) Aristóteles e suas interpretações escolásticas e, (2) a doutrina cristã. São complementares essas duas fontes, porque a doutrina cristã sofre ao final da escolástica a influência aristotélica, e ambas fornecerão as bases específicas para a formulação por juristas, teólogos e conselheiros reais na Espanha de uma justificativa sobre o direito de conquista e para a definição de uma política em relação aos povos do Novo Mundo. Vimos acima porque, em grande parte, esta é uma preocupação específica da Coroa espanhola, não se encontrando nada de semelhante entre portugueses, franceses e, posteriormente, ingleses. Essa questão também está ausente dos primeiros relatos dos italianos que se preocupavam mais em descrever e em entender a "descoberta" do que em legitimar uma conquista que, de fato, ainda não havia ocorrido. 
A terceira etapa (3) consiste em uma revisão da posição inicial à luz da experiência das primeiras décadas e da controvérsia entre conquistadores, colonizadores e missionários, quando a Coroa espanhola se vê obrigada a reformular suas leis e sua política em relação ao Novo Mundo, inclusive face à expansão territorial da conquista. Seu ponto alto é a famosa controvérsia entre Bartolomé de las Casas e Juan Ginés de Sepúlveda, o debate de Valladolid de I555. Mas, antes disso, o tratado de Francisco de Vitória (I486-I546), o grande nome da escola de Salamanca, sobre o direito de conquista das Índias Ocidentais, seu De Indis (1532), constitui sem dúvida uma das primeiras grandes contribuições a essa discussão, sendo também considerado um marco do início do Direito Internacional.

No primeiro contato com os povos do Novo Mundo encontramos cinco concepções gerais de natureza humana a partir das quais os europeus tentaram interpretar essa nova realidade que lhes causava especial perplexidade, como vimos acima (em relação à etapa I).

I) A primeira, oriunda da concepção cristã escolástica tradicional, baseia-se especialmente na narrativa bíblica. Esta concepção é universalista uma vez que segundo o Gênesis, todo ser humano provém da criação de Adão e, após o dilúvio, de Noé, cujos descendentes povoaram a terra. Com base no Antigo Testamento (por exemplo, II Reis, I7: 6, 23) surge também a hipótese de que os povos das Américas seriam as tribos perdidas de Israel, dispersadas pelos Assírios no deserto (PARFITT, 2002, particularmente capítulos 2 e 5). De qualquer forma, essa hipótese e a crença na descendência de Noé enfrentam de imediato a necessidade de explicar como esses seres humanos teriam vindo para o novo continente, questão que permanecerá em aberto durante muito tempo.

2) A segunda resulta de que a concepção universalista baseada na origem comum de toda a humanidade ganha uma nova força com o advento do Cristianismo quando a religião cristã é pregada, a partir da influência de São Paulo, para todos os homens e não apenas para os judeus. Como lemos na Epístola aos Gálatas $(3,28)$, “Já não há judeu nem grego, nem escravo nem homem livre, nem homem nem mulher, pois todos vós sois um em Cristo Jesus”. De acordo com essa concepção a salvação estaria a alcance de todos que pudessem receber a Revelação (SCHWARTZ, 2008).

3) A terceira baseia-se na tradição clássica grega e tem duas vertentes principais. A platônica em que encontramos os mitos da Atlântida (Crítias) e da Idade de Ouro (Timeu, Leis). E a aristotélica com base sobretudo no Tratado de Política, que influenciará particularmente a discussão da assim chamada "segunda escolástica" da escola de Salamanca quanto à discussão sobre o direito de conquista tendo como contraponto os direitos dos habitantes do Novo Mundo em autores, por exemplo, 
como Francisco de Vitória, mencionado acima. Segundo a posição aristotélica (Tratado de Política I252a), contudo, há uma hierarquia na natureza humana, estando o homem que habita a polis, o homem civilizado, no topo desta hierarquia, enquanto que os povos inferiores seriam "naturalmente escravos". Retomaremos esse ponto adiante.

4) A quarta tem sua origem em Heródoto nas Histórias, que em seus relatos de viagem enfatiza a diversidade entre os povos e compara os gregos por um lado com os persas e egípcios, que considera possuírem uma civilização sob muitos aspectos equiparável à grega, e por outro lado com outros povos vistos como bárbaros, como os citas do Mar Negro, que inclusive teriam praticado a antropofagia. Heródoto é importante por introduzir a discussão sobre a relatividade cultural, as chamadas "antíteses culturais", argumentando que o entendimento dos outros povos depende da valorização de seus hábitos, costumes e línguas. Sua obra foi influente no Humanismo do século XVI, principalmente após a edição latina por Henri Étienne que inclui uma Apologia pro Herodoto (I566) de sua autoria como introduçãó .

5) A quinta é a visão humanista que se desenvolveu sobretudo já no século $X V$ no contexto italiano em autores como Giovanni Pico dela Mirandola, enfatizando a dignitas hominis, reabilitando o homem como criador e empreendedor e defendendo a importância da educação humanista pelos studia humanitatis, a volta aos clássicos da tradição greco-romana em oposição à miseria hominis do período medieval em que o homem é considerado como ser marcado pela falha, pelo pecado original.

$\mathrm{Na}$ literatura espanhola que se segue ao descobrimento serão, sobretudo, a primeira, a segunda e a terceira que importarão na formação da caracterização dos nativos do Novo Mundo, de seus hábitos e costumes, isto é, de uma natureza que mesmo universal se manifesta de modo específico, contribuindo assim para a definição de seus direitos e da política de conversão ao Cristianismo.

Podemos ser tentados de imediato a simplesmente opor a concepção humanista, moderna portanto, e a aristotélico-tomista, tradicionalista, porém veremos que a questão é bem mais complexa e que talvez a oposição mais nítida, que pode ser representada pela controvérsia de Valladolid de 1555, mencionada acima, se dê entre os missionários e os juristas, que se baseiam em interpretações diferentes das mesmas fontes aristotélicotomistas e que representam interesses distintos e mesmo conflitantes.

\footnotetext{
${ }^{6}$ Ver a respeito da complexidade da relação entre os gregos e os outros povos: CARTLEDGE, 2002. Sobre a influência de Heródoto ver: HARTOG, 200I.
} 
A concepção universalista cristã fornecerá as bases para a doutrina dos missionários de que os habitantes do Novo Mundo são capazes de se converterem ao Cristianismo, devendo ser catequizados. O paralelo que se pode estabelecer é com a conversão dos bárbaros após a queda do Império Romano. Santo Agostinho abre em sua obra De catechizandis rudibus o caminho para esse processo de catequização em geral "daqueles que não têm instrução". Portanto, o Cristianismo deve ser estendido a todos os povos. Nesse sentido, os direitos desses povos defendidos pelos missionários não incluem um dos direitos humanos que consideramos mais centrais modernamente, cuja discussão começa nessa época em função das guerras religiosas entre protestantes e católicos: a liberdade religiosa. Nesse sentido, a conversão forçada ao Cristianismo, ao Catolicismo mesmo, é uma violação de direitos e uma incoerência. Por isso, encontramos com frequência a afirmação de que os povos nativos não tinham religião.

$\mathrm{O}$ aristotelismo será o ponto de partida dos juristas e políticos espanhóis para a legitimação da conquista, sobretudo em duas linhas, que exploraremos melhor, (I) a concepção da civitas, que caracterizará o homem civilizado em oposição ao bárbaro, ou seja, aquele que habita a selva (o "selvagem"); e (2) a teoria da escravidão natural, ou melhor, as interpretações medievais dessa teoria (CARTLEDGE, 2002, cap.6, p.I35).

Ambas as posições entram em conflito, contudo, na medida em que o Cristianismo defende uma visão universalista e o aristotelismo, pelo menos com base no texto da Política (citado acima), uma concepção hierárquica da natureza humana, em que os inferiores devem ser tutelados pelos superiores. A necessidade de revisão dessas concepções, à luz principalmente do contato com os povos do Novo Mundo é um dos fatores fundamentais do início de uma discussão de caráter antropológico.

\section{O conflito de teorias quanto à natureza humana}

O conflito de teorias, ou doutrinas, a assim chamada diaphonia, é umas das questões centrais da discussão filosófica na Antiguidade tardia, sobretudo como parte da crítica dos céticos aos dogmáticos (sobretudo estóicos e epicuristas). Em relação ao conflito, os céticos levantavam o problema do critério, ou seja, a necessidade para resolvê-lo de um critério para decidir entre as doutrinas que se excluíam e, ao mesmo tempo, a impossibilidade de se encontrar um critério, independente das doutrinas, que pudesse ser aplicado, já que todo critério é estabelecido por uma doutrina. Em consequência, temos o princípio cético da isosthenia (ou equipolência) das doutrinas em conflito e a impossibilidade de resolvê-lo argumentativamente. 
O descobrimento do Novo Mundo produziu um novo tipo de conflito, ou tornou um conflito já existente entre teorias da Antiguidade e do Cristianismo, particularmente difícil quando os europeus entraram em contato com os povos das Américas. Trata-se agora de um conflito sobre a natureza humana, sua universalidade ou sua diferença radical. Embora essa questão seja discutida desde a Antiguidade, por exemplo, de maneira bastante significativa em Heródoto, Platão e Aristóteles, o contato com os povos do Novo Mundo radicaliza esse conflito na medida em que revela uma nova realidade até então desconhecida e, sobretudo, desconhecida dos autores antigos e dos cristãos, as duas grandes autoridades da época. Não só a existência desses povos era desconhecida como sua diferença em relação aos europeus é radical como se vê desde os primeiros relatos. O desconhecimento, é claro, aprofunda a radicalidade da diferença, uma vez que de certa forma a diferença entre os povos da Antiguidade, inclusive a distinção entre bárbaros e civilizados, já havia de alguma maneira sido conceitualizada e absorvida. A descoberta de outros povos leva essa questão mais além e torna ainda mais difícil a interpretação de sua natureza e de suas culturas, alterando profundamente o sistema de crenças sobre a natureza humana e sobre a ordem natural então vigente e demandando uma nova formulação que inclua esses povos na ordem da natureza e da sociedade, forçando assim uma reconceptualização da natureza humana e de sua relação com a diversidade de hábitos e costumes?

Ao mesmo tempo, a descrição que Colombo apresenta em seu Diário dos primeiros contatos com os habitantes do Novo Mundo significa que esses povos até então desconhecidos passam a ser agora objeto de um contato direto com os europeus o que fará com que muitas das fantasias sobre seres monstruosos das fábulas antigas e medievais sejam desfeitas diante desse confronto entre a visão mítica e a realidade concreta (HOGDEN, 1964). Segundo Pocock, "os selvagens foram inventados, antes de serem descobertos" ${ }^{\prime}$.

Os habitantes do Caribe eram sobretudo os tainos com que Colombo primeiro fez contato e os caribs, ambos povos de origem Arawak que teriam emigrado da região hoje da Venezuela para as ilhas do Caribe. Tainos e caribs eram tradicionalmente rivais, os tainos considerados mais pacíficos e os caribs mais agressivos (pelos tainos). Dessa rivalidade geraram-se os dois mitos centrais que formaram a visão européia dos habitantes do Novo

\footnotetext{
${ }^{7}$ Sobre a antecipação dessa questão nos céticos antigos ver os 20. e Ioo. tropos de Enesidemo em: (Annas; Barnes, 1985).

${ }^{8}$ Pocock, Barbarism and religion, vol.4: Barbarians, savages and empires, parte III, "The New World and the problem of history", 2003.
} 
Mundo. Isso porque "taino" significa na língua desse povo "bom" ou "nobre", donde o "bom selvagem", "carib" significa "bravo", "feroz", daí o "bárbaro" e o "canibal”.

Serão basicamente três os caminhos seguidos na discussão sobre os povos do Novo Mundo. O primeiro tem por base a doutrina da escravidão natural em Aristóteles (Política, I 3-6); o segundo os autores antigos que discutem a distinção entre bárbaros e civilizados, não necessariamente considerando os bárbaros simplesmente como inferiores, como Heródoto, em relação aos persas e egípcios, por exemplo, e Tácito, em relação aos germânicos; o terceiro, autores cristãos de São Paulo a Santo Agostinho, que adotam uma teoria da universalidade da natureza humana, inspirados pela origem comum da criação humana, o mito adâmico.

Essas diferentes posições vão, por sua vez, gerar diferentes tipos de conflito: divergências entre as interpretações de Aristóteles, divergência entre as visões baseadas em Aristóteles e as concepções cristãs universalistas, divergências entre estas e as interpretações humanistas, que levam em conta a diversidade cultural e vêem mesmo nos habitantes do Novo Mundo formas alternativas de vida que podem ensinar aos europeus uma lição moral e devem levá-los a refletir sobre sua suposta superioridade (por exemplo, no caso de Montaigne em Os canibais).

A discussão sobre os direitos humanos, no caso sobre os direitos dos povos nativos, tem uma de suas principais origens nesse contexto e se dá inicialmente sob o pano de fundo desse conflito de teorias. Portanto, não emerge de início efetivamente uma doutrina sobre "direitos dos povos indígenas", mas um conflito de posições doutrinárias. Esse conflito tem dois aspectos que se articulam. Em primeiro lugar uma divergência sobre a interpretação das autoridades tradicionais, sobretudo Aristóteles e seus intérpretes medievais, em segundo lugar sobre a aplicação dessas interpretações à natureza dos povos nativos, sendo que a determinação dessa "natureza" é ela própria objeto de controvérsia9

\section{A escravidão natural}

Um dos argumentos centrais em favor da legitimação da conquista no caso do Novo Mundo é a famosa "doutrina da escravidão natural", atribuída a Aristóteles. A formulação aristotélica foi intermediada por seus intérpretes e comentadores medievais, sobretudo São Tomás de Aquino ${ }^{\mathrm{IO}}$ e posteriormente pelo tomista cardeal Caetano (I469-I534).

\footnotetext{
${ }^{9}$ Ver a esclarecedora análise dessa questão em: (PAGDEN,I982).

${ }^{\text {Io }}$ As principais fontes são o tratado da Política I, caps.3-7 e a Ética a Nicômaco, VII.
} 
Contudo, não há uma única concepção grega de escravidão, nem mesmo é claro como se deve interpretar a defesa por Aristóteles da "escravidão natural". Trata-se muito mais na Política de um conceito examinado e discutido do que da defesa analítica e argumentativa de uma doutrina, como Aristóteles faz em outros textos, e certamente não se refere ao que se passava na Grécia naquele período histórico, em que a escravidão foi algo bem mais complexo, variando em diferentes regiões e cidades. Devemos nesse sentido distinguir a posição dos filósofos como Platão e Aristóteles, que formulam posições teóricas e a situação histórica grega (BARKER, 1978).

O termo grego “doulos”, traduzido comumente por escravo, possui um significado bastante distinto do encontrado no século XVI, já influenciado pela terminologia latina, segundo a qual o termo tardio sclavus é derivado do nome do povo "eslavo", uma vez que em Roma um grande número de escravos era de origem eslava, embora também esse termo fosse usado de modo impreciso. No latim clássico o termo empregado é "servus", sem distinção entre o servo e o escravo. Os gregos, por sua vez, usavam outros termos para o que denominamos escravos, por exemplo, hilotas, característicos de Esparta (heilotai, servos pertencentes ao estado), tendo diferenças em relação a outras cidades gregas, e andrapodos, tal como usado por Tucídides, especificamente o escravo prisioneiro de guerra e ou vendido por um mercador. (CARTLEDGE, op.cit. pp. I5I-I52).

Historicamente, a prática social da escravidão na Grécia Antiga teve diferentes formas em diferentes épocas e em diferentes regiões, sendo possível, em vários casos o escravo recuperar a liberdade, por exemplo, por recompensa por sua participação na guerra, e mesmo em alguns casos receber a cidadania (WIEDEMANN, I98I). Havia escravos que pertenciam ao estado e escravos que pertenciam a indivíduos, escravos que trabalhavam nas minas e escravos domésticos (os oiketai) (DAVIS, 1966).

Uma análise do texto de Aristóteles na Política (I, 3-7) revela um contraste por um lado entre uma concepção de escravidão definida pela lei (nomos), ou pelas leis das diferentes regiões, convencional e variável, geralmente caracterizando o escravo como alguém tomado como prisioneiro, na maioria dos casos, de guerra ou até por endividamento e, por outro lado, a "escravidão natural". O próprio Platão teria sido feito prisioneiro quando de sua primeira viagem a Sicília e vendido como escravo, sendo depois resgatado por um amigo ${ }^{\text {II }}$. Aristóteles contrapõe à escravidão legal uma concepção de "escravidão natural". Muito tem sido escrito sobre essa teoria, sendo que alguns filósofos e

\footnotetext{
${ }^{\text {II }}$ Segundo a biografia de Platão em Diógenes Laércio, I988.
} 
intérpretes de Aristóteles a vêem como uma mancha em sua reputação ${ }^{\mathrm{I2}}$. Contudo, talvez não encontremos nesse texto propriamente uma "teoria da escravidão natural", mas apenas um exame de várias concepções sobre o papel do escravo na sociedade como parte de uma discussão mais ampla sobre a autoridade política em suas diversas formas, inclusive a do senhor sobre o escravo (HEATH, op.cit, pág. 344).

Para Aristóteles o que leva alguém a ser considerado naturalmente escravo seria sua condição de inferioridade intelectual, sua incapacidade de autonomia e sua dependência de um mestre ou senhor (despotes). A justificativa natural da escravidão se opõe a uma justificativa de acordo com a lei (nomos), ou convencional (por homologia), ou ainda por razões econômicas, na medida em que o escravo é útil para a produção ou como propriedade, podendo ser vendido.

Sua formulação é complexa porque este conceito pode ser considerado como meramente hipotético, uma vez que Aristóteles não menciona efetivamente nenhum povo que tenha historicamente essas características, nem fica claro se seriam características de um povo como tal ou de indivíduos. Seu argumento pode ser entendido como um contraponto à escravidão legal, como uma tentativa portanto, com base em uma concepção de natureza humana, de restringir a possibilidade de escravidão, que não dependeria mais da possibilidade de uma sociedade definir convencionalmente, logo, arbitrariamente, quem poderia ser escravo, limitando a escravidão apenas aos casos em que se justificaria pela natureza inferior dos indivíduos. Assim, não é qualquer homem que pode arbitrariamente se tornar escravo. Essa posição de Aristóteles deve ser entendida portanto no contexto da sociedade grega de sua época, levando-se em conta os exemplos históricos e como parte da crítica aristotélica ao convencionalismo político e social, assim como de sua defesa do caráter natural da sociedade, já que “o homem é um animal político" por natureza. Aqueles que vivem fora da polis, de um modelo específico de sociedade, portanto, estão como que excluídos dela, naturalmente e não porque uma lei ou uma decisão política os excluiu ou os definiu como escravos. Isso excluiria, por exemplo, a possibilidade, escandalosa para os filósofos, de Platão ser vendido como escravo, o exemplo flagrante da "injustiça” a que a escravidão legal poderia levar.

Um dos pontos de partida fundamentais em favor da legitimidade da conquista consiste na tese aristotélica que só na polis o homem pode realizar plenamente sua condição humana, enquanto membro de uma comunidade (koinonia), logo enquanto

\footnotetext{
${ }^{12}$ Ver: (Heath, 2008, pp. 243-70) e (Tosi, "Aristóteles e a escravidão natural", 2003).
} 
cidadão. É exatamente porque os habitantes do Novo Mundo não vivem essa realidade que se pretenderá justificar a conquista como "missão civilizatória".

Há, porém, um outro conceito de escravidão, de caráter político, encontrado já em Heródoto (Historias, 7, I04.4) e empregado também por Aristóteles (Política, VI, 2), que opõe o cidadão grego enquanto livre e sujeito apenas à lei (nomos) aos súditos de impérios como o persa e o egípcio que eram como escravos de seus monarcas.

Portanto, o argumento empregado será que igualmente nas Américas, os nativos não são capazes de uma razão autônoma e quando muito são súditos de impérios (por exemplo, Astecas e Incas), homens que já vivem como escravos e por isso podem ser escravizados pelos colonizadores. A escravidão, embora ainda limitada numericamente, era já comum na Europa do final do século XV e início do XVI. Os povos islâmicos no Mediterrâneo possuíam escravos e os portugueses haviam estabelecido (I482) o forte de São Jorge da Mina na África Equatorial (atualmente em Gana), como um entreposto para o comércio de ouro e de escravos. É significativo que da expedição de Diogo de Azambuja (I48I) enviada para fundar esse entreposto fizesse parte um marinheiro genovês, Cristóvão Colombo.

\section{Os discursos sobre os direitos dos povos indígenas e as leis de Burgos}

Essa análise restringe-se apenas a algumas indicações sobre período inicial do descobrimento e ocupação do Novo Mundo, quando as primeiras imagens de seus habitantes se formam e quando se formulam os desafios a serem enfrentados. Meu contexto será essencialmente o da descoberta até 1513 com a revisão das Leis de Burgos. Portanto, ao momento em que a ocupação e colonização está praticamente restrita ao Caribe, antes da efetiva ocupação da Tierra Firme (inicialmente correspondente ao território hoje do Panamá, Venezuela e Colômbia no Caribe), quando o Requerimiento é utilizado pela primeira vez pelo colonizador Pedrarías Ávila. Esse contexto muda com o contato com os impérios Asteca, Maia e Inca que forçarão uma nova definição dos povos das Américas.

Já em I495 em um decreto de Madri os reis católicos tentaram regulamentar a ocupação dos territórios conquistados, até aquele momento apenas ilhas no Caribe, controlando a imigração de espanhóis para esses territórios e a venda de índios como escravos. Na Andaluzia recém conquistada havia um mercado regular de escravos desde a ocupação muçulmana, porém surge a nova questão sobre a legitimidade da venda dos índios como escravos. Isso se dá através do apelo à natureza pacífica ou hostil destes índios, 
sendo o critério de legitimação para aprisioná-los ou vendê-los sua natureza selvagem, os "bárbaros canibais". Contra eles se poderia fazer uma "guerra justa", contudo, uma vez convertidos ao cristianismo e batizados os índios não poderiam mais ser vendidos como escravos. Certamente isso era contrário aos interesses dos primeiros colonizadores, mas não dos missionários interessados na expansão do Cristianismo.

Porém, a virada dos relatos dos navegadores e cronistas para o discurso sobre a legitimidade da conquista e os direitos dos povos indígenas têm como ponto de partida o famoso sermão do dominicano Frei António de Montesinos em Santo Domingo, em La Española, em dezembro de I5II, menos de duas décadas após o descobrimento. Tomando como mote as passagens dos Evangelhos de São Lucas (3:4-6) e de São Mateus (3:3), sobre "a voz que clama no deserto", Frei Montesinos faz uma denúncia vigorosa dos maus tratos dos povos indígenas pelos colonizadores espanhóis e do sistema de encomiendas, pelos quais recebiam concessões de terras a serem trabalhadas pelos indígenas. Montesinos questiona, “Acaso não são eles homens, acaso não possuem razão e almas”, levantando precisamente os pontos sobre a natureza dos nativos em torno dos quais se desenvolverá a discussão, sua racionalidade e sua natureza espiritual, o que os caracterizaria apesar da diversidade de hábitos, como seres humanos possuidores da mesma natureza que os europeus. Montesinos inverte assim o argumento dos colonizadores denunciando os espanhóis como os "verdadeiros bárbaros" pelo modo cruel e anticristão como tratavam os nativos.

Em consequência é convocado à Espanha e uma comissão de juristas e conselheiros reais reúne-se em Burgos para debater a questão. É curioso que o humanista Pedro Mártir d'Anghiera, cronista oficial do rei, homem de imenso prestígio na corte, membro do Conselho das Índias, com vários escritos sobre o Novo Mundo e sob certos aspectos um crítico da colonização, jamais tenha sido chamado a opinar sobre esta questão. A própria composição da comissão parece já revelar os interesses em jogo. A visão humanística é preterida, prevalecendo uma discussão teológico-jurídica.

As Leis de Burgos, que resultaram desse debate, foram promulgadas a $27 \mathrm{de}$ dezembro de 1512 com o objetivo de regularizar o sistema de encomiendas e assegurar a catequização dos nativos, evitando os maus tratos. Sua eficiência foi discutível e dado o reduzido poder de fiscalização da coroa e os interesses dos colonizadores sua aplicação foi restrita, "se acata, pero no se cumple" era a fórmula empregada pelos colonizadores, uma atitude que será bastante comum na colonização do Novo Mundo e que retrata a autonomia resultante da efetiva distância entre as colônias e o poder central. Do ponto de vista jurídico, contudo, sua importância, ainda que formal, é grande enquanto reconhecimento dos direitos dos povos nativos. Ainda assim esse reconhecimento parece 
pressupor a concepção aristotélica de que os povos inferiores devem se "beneficiar", dada a sua incapacidade de decidir, da superioridade intelectual dos povos superiores, no caso os colonizadores e devem trabalhar para eles já que por natureza são adequados mais ao trabalho manual do que ao intelectual. Trata-se portanto historicamente de uma aplicação efetiva da doutrina aristotélica da escravidão natural tal como interpretada em relação a este novo contexto. Por outro lado, e em conflito com essa posição, a visão cristã justifica o esforço de conversão dos nativos com base na concepção universalista de que todos podem ser salvos (SCHWARTZ, 2008, op.cit).

Essas leis foram reformuladas já em 1513 , dado os protestos dos encomendieros que alegaram que inviabilizavam a colonização, mas seu principal desdobramento foi o famoso Requerimiento redigido pelo jurista espanhol Palácios Rúbios que vigorou até 1542, quando as leis de Burgos foram substituídas pelas Nuevas Leyes de Índias. O Requerimiento deveria ser acompanhado de uma ata notarial certificando sua leitura na presença dos povos nativos que eram então convocados a aceitar a soberania espanhola e converter-se ao Cristianismo $^{\mathrm{I} 3}$. É significativa sua fórmula de abertura, “De parte Del Rey Don Fernando y de su hija, Doña Juana, reina de Castela e León, domadores de pueblos bárbaros..." [meu grifo], quando é evocada a natureza "bárbara" desses povos que por isso devem ser subjugados; porém paradoxalmente supõe-se ao mesmo tempo que manifestem entendimento do texto legal e aceitem "voluntariamente" a soberania espanhola. A visão europeia dos povos do Novo Mundo não consegue ser formulada sem ambivalências.

Seu exemplo é sem paralelo na história das conquistas do Novo Mundo e já foi considerado um absurdo ou um formalismo legal vazio. Contudo, há precedentes na tradição espanhola, por exemplo, com a conversão em massa de judeus no século XV e de mouros no início do século XVI e posteriormente com os inquéritos da Inquisição (KAMEN, 20I4).

Pode-se supor que a Espanha dividida em vários reinos e por muitos séculos uma sociedade multiétnica e multirreligiosa em que conviviam cristãos, judeus e muçulmanos, no esforço de constituir uma nova unidade política ao final do século XV volta-se contra suas minorias e busca impor uma identidade nacional. $\mathrm{O}$ formalismo jurídico passa a ser um instrumento político nesse sentido, visando a legitimação do novo estado cuja unidade era ainda instável e que se vê nesse momento na contingência de anexar um novo território de dimensões ainda não avaliadas e habitado por povos ainda desconhecidos.

\footnotetext{
${ }^{13}$ Texto completo no site www.gabrielbernat.es/.../requerimiento/requerimiento.html
} 
As bases aristotélicas dessa política são ambíguas. O Requerimiento por um lado vai contra a concepção aristotélica por procurar regular a prática da submissão dos povos nativos pela lei, arbitrária enquanto tal; por outro lado, evoca a noção da natureza "bárbara" dos nativos, daqueles como suponha Aristóteles que habitam a periferia do mundo civilizado, para subjugá-los. Os missionários recorrem ao universalismo cristão, segundo o qual todos os homens podem ser salvos, portanto sua natureza deve torná-los capazes de entender a mensagem cristã, mas ignoram ou consideram bárbaras as práticas religiosas desses povos.

O Requerimiento resulta assim de um compromisso político entre os missionários dominicanos e os colonizadores espanhóis, uma tentativa de legitimar a conquista dentro dos limites de um tratamento cristão dos nativos, supostamente dando-lhes escolha de se converterem e de se tornarem súditos do rei. Há certamente aí uma analogia com a conversão forçada de mouros e judeus ao Cristianismo como alternativa a sua expulsão. A analogia cessa quando se leva em conta que nesse caso, os povos nativos habitavam as suas próprias terras e os invasores eram os colonizadores e os missionários.

\section{Conclusão}

No desenvolvimento do pensamento filosófico, político e jurídico desse período, o conceito de "direito dos povos nativos" do Novo Mundo foi formulado assim inicialmente em oposição aos conceitos de "direito de conquista" e de "guerra justa" e portanto contra a concepção de uma natureza humana bárbara ou selvagem pressuposta por esses conceitos que legitimariam a colonização. Reflete assim um conflito entre um projeto político colonialista e uma missão evangelizadora, cada qual buscando fundamentar-se em concepções tradicionais de natureza humana desde os filósofos gregos aos pensadores cristãos, em interpretações cuja ambivalência reflete esse conflito.

Contudo, de um ponto de vista histórico, na verdade temos em primeiro lugar a denúncia de Montesinos e apenas posteriormente a necessidade de legitimação políticojurídica, que deve ser entendida no contexto da formação da Espanha no século XV e do império de Carlos V no início do XVI.

Temos então inicialmente o fato histórico do descobrimento e do impacto que causou pela descoberta de novas terras e de povos até então desconhecidos. A rota para o Oriente continuou a ser a ambição dos navegadores europeus, mas a nova realidade descoberta teve que ser interpretada e compreendida dado o seu inesperado. Embora houvesse desde a Antiguidade suspeita de que havia terras naquela região, daí a 
preocupação dos tratados entre Portugal e Espanha, não se tinha conhecimento nem remoto do que essa nova realidade incluía e significava. Após a descoberta e com os primeiros conflitos deu-se o início da ocupação e a necessidade de se propor uma política para o Novo Mundo. Para a Europa, inclusive para Carlos V, o mundo europeu continuou sendo a prioridade, com a consolidação de seu império até a derrota dos turcos na batalha de Lepanto. O Novo Mundo permaneceu em grande parte desconhecido até praticamente o século XVII, quando o processo de colonização e de exploração das riquezas se intensificou.

Duas questões parecem se entrelaçar nessa discussão. A primeira diz respeito à natureza humana e como a concepção grega, sobretudo aristotélica ${ }^{\mathrm{I} 4}$ foi reinterpretada por seus comentadores medievais à luz da doutrina cristã. A descoberta dos povos do Novo Mundo coloca em questão essas interpretações, que parecem insuficientes, diante da novidade desses povos e de sua diversidade cultural radical. A segunda é a disputa política entre o alcance do poder do papa e do poder do imperador, acerca da legitimidade do poder temporal do papa e da legitimidade do poder do imperador sobre novas terras conquistadas, portanto sobre a expansão do imperium. Sua origem se encontra já nas posições de Guilherme de Ockham no século XIV, contra o poder temporal do papa. Essa disputa adquire uma nova dimensão quando os missionários evocam o poder do papa e da Igreja como se sobrepondo ao da coroa e dos colonizadores, argumentando que o soberano cristão está obrigado a cumprir as leis de Deus e os ditames da Igreja e a política para o Novo Mundo deve seguir esses critérios, significando sobretudo a expansão da Cristandade. O Concílio de Trento (I545-I563) que se inicia logo em seguida radicalizará as posições a esse respeito.

A discussão sobre a natureza humana provocada pelo impacto dos descobrimentos e as questões que levantou sobre os direitos dos povos indígenas constitui um dos pontos fundamentais da origem da modernidade, sobretudo do pensamento político moderno, exatamente no que tem de universalista, revelando mais um aspecto segundo o qual a Modernidade foi fortemente influenciada por questões de ordem teológica e como a fronteira entre o religioso e o político é menos nítida do que posteriormente se supôs ${ }^{15}$. Paradoxalmente, contudo, a concepção universalista de natureza humana serviu para legitimar a inclusão dos povos nativos na Cristandade e a defesa de seus direitos e de sua

\footnotetext{
${ }^{14}$ Quanto a essa questão, sobretudo na Política. Em outros textos, p.ex. na Metafísica em relação ao conhecimento e no $\mathrm{Da}$ interpretação em relação ao significado, Aristóteles parece manter uma posição universalista, quando afirma, p.ex. que "todos os homens têm o desejo de conhecer" (Met.I,I) e que as "afecções da alma são as mesmas para todos" (Da int., I, I).

${ }^{15}$ Ver a esse respeito, o clássico: (BLUMEMBERG, I985) e mais recentemente: (GILLESPIE, 2008).
} 
dignidade não significou naquele momento o reconhecimento de suas culturas, ou, no vocabulário da época, de suas práticas, hábitos e costumes, inclusive os religiosos. Destruídas em nome da conquista, da exploração dos recursos e da expansão do império ou em nome de sua incorporação à Cristandade, essas culturas em grande parte se perderam irremediavelmente.

\section{Referências Bibliográficas}

ANNAS, Julia; BARNES, Jonathan Barnes. The modes of skepticism: ancient texts and modern interpretations. Cambridge University Press: 1985.

AQUINAS, Thomas. Commentary on Aristotle's Politics. Trad. Richard J. Regan, Indiana/Cambridge: Hackett, 2007.

ARISTÓTELES. Política I. EDIPRO, 2009. . Ética a Nicômaco. EDIPRO, 2007. . Metafísica. EDIPRO, 2012. São Paulo: UNESP, 2013.

BLUMEMBERG, H. The Legitimacy of the Modern Age. Paperback, 1985.

BARKER, Ernest. Teoria política grega. Brasília: UnB, 1978.

CARTLEDGE, Paul. The Greeks, a portrait of self and others. Oxford: Oxford University Press, 2002.

D'ANGHIERA, Pierre Martyr. De orbe novo decades et Oceana Decas. Paris: Les Belles Lettres, 2003.

DAVIS, David Brion. The problem of slavery in western culture. Oxford: Oxford University Press, 1966.

DUMONT, Jean. La vraie controverse de Valladolid: premier débat des droits de l'homme. Criterion: Paris, 1995.

FAURÉ, Christine. "Ce qui n'est pas dit dans la Déclaration de 1948, c'est ce qu'il faut entendre par universalité" In: Les Déclarations des droits de l'homme de I789. Paris, Payot, I988. GARRET, Wilbur E. (editor). "Our search for the true Columbus landfall” In: National Geographic, vol.I70, n.5, 1986.

GILLESPIE, Michael Allen. The theological origins of modernity. Chicago: University of Chicago Press, 2008.

HARTOG, François. Le mirroir d'Hérodote. Paris: Gallimard, 200I.

HEATH, Malcolm. "Aristotle on natural slavery" IN: Phronesis, 53, 2008, págs.243-70. 
HEER, Fredrich. The Holy Roman Empire. Phoenix: London, 1995.

HOGDEN, Margaret T. Early anthropology in the sixteenth and seventeenth centuries. Philadelphia: University of Pennsylvania Press, 1964.

JULLIEN, François. De l'universel, de l'uniforme, du commun et du dialogue entre les cultures. Paris: Fayard, 2008.

KAMEN, Henry. The Spanish Inquisition. Yale University Press, 4a.ed., 2014.

LAÉRCIO, Diógenes. Vida e doutrina dos filósofos ilustres, Brasília, UnB, 1988.

LE NOUVEAU MONDE, récits de Amerigo Vespucci, Christophe Colomb, Pierre Martyr dAnghiera. Préface de Tzevetan Todorov. Paris, Les Belles Lettres, 2004.

LE NOUVEAU MONDE: Les Voyages d'Amerigo Vespucci. Traduction, introduction et notes de Jean-Paul Duviols. Paris: Chandeigne, 2005.

PARTITT, Tudor. The lost tribes of Israel: a history of a myth. London: Weidenfeld and Nicolson, 2002.

PAGDEN, Anthony. The fall of natural man. Cambridge: Cambridge University Press, I982. POCOCK, J.G.A. Barbarism and religion, vol.4: Barbarians, savages and empires, parte III, "The New World and the problem of history". Cambridge: Cambridge Univ. Press, 2003.

TEIXEIRA, Dante Martins; PAPAVERO, Nelson. Os primeiros documentos sobre a história natural do Brasil (I50o-I5II): viagens de Pinzón, Cabral, Vespucci, Albuquerque, do Capitão de Gonneville e da Nau Bretoa. Museu Paraense Emílio Goeldi, 2002.

THOMAS, Hugh. Rivers of gold: the rise of the Spanish Empire from Columbus to Magellan. New York: Random House, 2003.

TOSI, Giuseppe Tosi. “Aristóteles e a escravidão natural” IN: Boletim do CPA, Campinas, n. I5, jan.ljun. 2003.

SCHWARTZ, Stuart B. All can be saved: religious tolerance and salvation in the Iberian Atlantic World. New Haven \& London: Yale University Press, 2008.

WIEDEMANN, Thomas. Greek and Roman Slavery. London: Routledge, I98I, reimpressão 2005. 